\title{
The Paretian Turn
}

The foundation of the theory of rational choice, and its discontents

\section{Luigino Bruni}

\section{(2) OpenEdition}

\section{Journals}

Electronic version

URL: http://journals.openedition.org/ress/2510

DOI: $10.4000 /$ ress. 2510

ISSN: $1663-4446$

\section{Publisher}

Librairie Droz

\section{Printed version}

Date of publication: 15 December 2013

Number of pages: 47-64

ISBN: 978-2-600-01805-0

ISSN: 0048-8046

\section{Electronic reference}

Luigino Bruni, «The Paretian Turn », Revue européenne des sciences sociales [Online], 51-2 | 2013, Online since 01 January 2017, connection on 19 March 2020. URL : http://journals.openedition.org/ress/ 2510 ; DOI : https://doi.org/10.4000/ress.2510 


\title{
THE PARETIAN TURN
}

\section{THE FOUNDATION OF THE THEORY OF RATIONAL CHOICE, AND ITS DISCONTENTS*}

\author{
LUIGINO BRUNI \\ Lumsa University (Rome) \\ luigino.bruni@gmail.com
}

\begin{abstract}
Using his "naked fact" methodology of rational choice theory, this article discusses Pareto's re-foundation of microeconomics. Before Pareto, first generation neoclassical economists based their approach on theoretical and experimental psychology, something methodologically similar to what contemporary behavioural economics does. During the $20^{\text {th }}$ century, Pareto, and mainstream microeconomists, treated economics as a separate science of rational choice, completely independent of psychology. But Pareto faced fundamental problems that were never fully solved. The paper suggests that the Paretian turn delayed a fruitful encounter between economics and psychology suggested without success to Pareto by Pantaleoni at an early stage of Pareto's revolution. However, and judging by what is going on in economics today, Pantaleoni's, Edgeworth's or Jevons' psychological approach to economics was not as unscientific and metaphysical as Pareto thought and wrote.
\end{abstract}

Keywords: Vilfredo Pareto, Maffeo Pantaleoni, microeconomics, psychology, rational choice theory.

Résumé. Cet article examine la re-fondation par Pareto de la micro-économie à partir de sa méthodologie d'une théorie du choix rationnel basée sur les faits purs. Avant Pareto, les économistes de la première génération néo-classique avaient fondé leur approche sur une psychologie théorique et expérimentale similaire, d'un point de vue méthodologique, à ce que font aujourd'hui les économistes «behavioristes». Au cours du Xxe siècle, Pareto, et avec lui les micro-économistes «mainstream», ont traité l'économie comme une science séparée, fondée sur l'analyse du choix rationnel et complètement indépendante de la psychologie. Pourtant Pareto fit face à des problèmes fondamentaux, jamais vraiment surmontés. Dans cet article, l'auteur soutient que le tournant Parétien a contribué à reporter une rencontre fructueuse entre économie et psychologie, laquelle avait été suggérée sans succès à Pareto par Pantaleoni dès les premiers stades de la révolution parétienne. Cependant, et à en juger par le devenir de la science économique aujourd'hui, l'approche psychologique de l'économie d'un Pantaleoni, d'un Edgeworth ou d'un Jevons n'était pas aussi non-scientifique et métaphysique que le pensa et l'écrivit Pareto.

Mots-clés: Vilfredo Pareto, Maffeo Pantaleoni, micro-économie, psychologie, théorie du choix rationnel.

* This paper is based on Bruni and Sugden (2007). 


\section{INTRODUCTION}

Pareto is among the very few economists that are classics in the history of economic analysis and in other disciplinest. Therefore, it is very difficult to pinpoint "the" main contribution of Pareto to the advancement of sciences. In the economics tradition, however, there is a common agreement among scholars that Pareto's most important heritage is his reformulation of the theory of choice, free from any psychological and unempirical element, that does not require "metaphysical" concepts such as the hedonist "utility" or even his own "ophelimity".

The $\mathrm{xx}^{\text {th }}$ century has been in its greater part-from the I930's to the I990's-Pareto's century. But the beginning of the $\mathrm{XXI}^{\mathrm{st}}$ is showing a new paradigm shift-the so-called "behavioural economics"-which draws on the theoretical and methodological approaches of psychology in explaining economic phenomena, that is somehow a reappearance of the pre-Paretian paradigm, that of Edgeworth, Pantaleoni or Jevons, based on psychology, hedonism and subjective introspection. ${ }^{3}$ In fact, viewed in historical perspective, behavioural economists are now trying to reverse a fundamental shift in economics which took place from the beginning of the $\mathrm{xx}^{\text {th }}$ century: the so-called "Paretian turn"

I It is, in fact, telling that the first paper of the first issue of this journal was by Raymond Aron (Cahiers Vilfredo Pareto, 1963, I, p.7-26)

2 Personally, I consider that Pareto's Cours d'Économie politique (1964 [1896-1897]) is an underrated and forgotten book. As economic treatise, the Cours is not inferior to the Manual of Political Economy (197I [1906]). In particular, the "entrepreneur"'s theories, or those of the different forms of market, are more original and interesting than those present in the Manual. There are, at least, two reasons behind this neglect: Pareto's methodological turn just few years after the Cours, and the absence (untill today) of an English translation of the Cours.

3 The roots of the behavioural turn is older than the I880's. A major concern from the early 1950s was to extend the theory of rational choice to deal with risk and uncertainty. The "microfoundations" and "rational expectations" literatures sought to replace the psychologically and empirically-based assumptions of Keynesian macroeconomics with assumptions about the preferences and beliefs of rational agents (this is also why Dusenberry's "sociological" theory of consumption became much less popular that Modigliani's or Friedman's). The new sub-disciplines of public choice, law and economics, contract and agency theory, or even the new institutional economics, extended rational-choice modelling to areas of social life that had previously been thought of as non-economic. The pervasive applications of game theory, based on rational agents, has pushed forward the revolution, and a widespread hope that, by providing a universal grammar of choice, game theory would soon unify social sciences. 
(Bruni and Sugden, 2007). This shift, initiated by Vilfredo Pareto and completed in the I930s and I940s by John Hicks, Roy Allen and Paul Samuelson (among others), economists who all explicitly linked their methodology of economics to Pareto $^{4}$, eliminated psychological concepts from economics by basing economic theory on principles of rational choice, principles that were a priori without the need for any (real) empirical foundation. Against this methodology, behavioural economics reacted and presents itself today as a counter-revolution.

In claiming that economics should cut itself off from psychology, Pareto was proposing a major deviation from current understandings of the nature of economic explanation. In proposing the separation of economics from psychology, or in the elimination of psychology from any scientific analysis in social

4 Interesting it is the correspondence among leading English and American economists around the proposal to translate the Manuale di Economia Politica into English. In fact, on the occasion of the $50^{\text {th }}$ anniversary of the first edition of Pareto's Manual (1906), the American Economic Association, encouraged "by the general enthusiasm with which the translation of Walras by Jaffé has been received by the profession", considered the possibility "to arrange the translation of Pareto's Manuale from the Italian" (Letter from John Perry Miller, chairman Research and Publications committee AEA, to Austin Robinson, Secretary of the Royal Economic Society, 27 January 1956). In particular, Parry Miller intended to involve the Royal Economic Society in "a cooperative venture with the A.E.A on this matter similar to the arrangement provided for Walras". After several letters interchanged between Robinson, Miller, the publisher George Allen \& Unwin (the RES publisher), Hicks, Georgescu Roegen, with references to advices given by Sraffa, Jaffé and Stigler among others, on 24 October 1956 Perry Miller wrote to Georgescu-Roegen (who was offering himself as support for the translation) that "unfortunately this project was for awhile tangled up in various complications". 24 October is the last letter referring to the project of a $50^{\text {th }}$ anniversary English translation. Alexander Morin, Managing editor of University of Chicago Press, in July 19, 1956 wrote to Miller that "we have been enable to locate a suitable translator", and the project was withdrawn. In the 1962, interested in the English translation of Manuale, the Asia Publisher House (London) contacted Hicks. Hicks passed the letter to Robinson, with this interesting comment: "I feel, however, strongly that what is needed is a good English translation, better printed than the French (where the diagrams are perfectly horrid)" (6th March 1962). Finally, Robinson replied to Asia House with some notes: "The French edition contained considerable additions by Pareto himself, and Mr. Sraffa thinks that it would be right to use the French edition for purposes of translation, though it may contain mistakes that were not discovered by Pareto [...] Mr Sraffa is not quite certain whether the second Italian edition, which is, I understand, of same date as the French edition, incorporated the improvements made by Pareto for the French edition" (I2 March 1962). All letters are at the Austin Robinson Archive, LSE Library Archives (PA357, RES minute books), A critical English edition of Pareto's Manual should be soon available, edited by Aldo Montesano et al. (2014, Oxford University Press). 
sciences (because, for him, empirically immature), Pareto was very explicit. In the introduction to the paper in which he first outlines his new approach to the theory of choice, he claims as one of its main achievements "every psychological analysis is eliminated" (I982 [1900], p.366)5 . In a letter dated of 1897 to the philosopher Adrien Naville, he writes: "It is an empirical fact that the natural sciences have progressed only when they have taken secondary principles as their point of departure, instead of trying to discover the essence of things. [...] Pure political economy has therefore a great interest in relying as little as possible on the domain of psychology" (quoted in Busino, 1964, p.xxiv).

In this paper, that is part of a more general research on Pareto, from Bruni and Guala (200I) to the editing of the Manual of Political Economy critical English edition (forthcoming with Oxford University Press). In particular, this paper is in continuity with, or a representation of, the research presented in Bruni and Sugden (2007), where one can also find general framework of theses that here are just mentioned and little discussed.

\section{THE METHODOLOGY OF NAKED FACTS}

Pareto was convinced that economic theories should be deduced from firmly established empirical propositions about "objective" and observable choices rather than about "subjective" and metaphysical sensations. He claims that everything that is significant in the existing economic theory (i.e. that of Walras) can be derived from the "fact" of curves of indifference, without any recourse to concepts such as utility or pleasure:

this entire theory $[\ldots]$ rests on no more than a fact of experience, that is, on the determination of the quantities of goods which constitute combinations between which the individual is indifferent. The theory of economic science thus acquires the rigor of rational mechanics; it deduces its results from experience, without bringing in any metaphysical entity (1971 [1909], ch.3, §36b). 
Or in other words: "I am not interested in the reason why man is indifferent between [one thing and another]: I notice the pure and naked fact" (Pareto's letter to the mathematician Herman Laurent I989 [1899], p.288).

Despite the way he uses the term "metaphysical" for psychology, Pareto accepts that psychology is more fundamental than economics, in the same sense that physics is more fundamental than chemistry or biology. In principle, to him, economic phenomena have (or, in principle, can have) psychological explanations, just as chemical phenomena have physical explanations. But, he believes, each science makes progress by finding its own fundamental laws, and making deductions from those laws. His proposal is that economics should constitute itself as a separate science-separate, in particular, from psychology and from sociology, also because Pareto was not convinced about the epistemology of the psychology of his time.

Economics - surely pure economics - is to be the science of logical action. The distinction between "logical" and "non-logical" actions is fundamental to Pareto's methodology. Following classical physics and Mill's methodology, Pareto describes his methodology as one of analysis and synthesis. To investigate complex social phenomena, we must break them down into simpler components, and analyse each component separately. Analysis is the role of science; synthesis-re-assembling the components-is essential for practice (197I [1909], ch.I, §2I-26). When Pareto distinguishes between "pure" and "applied" economics ${ }^{6}$, pure economics is understood as science while applied economics is understood as practice. The implication is that applied economics might need to draw on the findings of sociology or psychology. Nevertheless, pure economics is concerned only with "logical" action. As it is well known to Paretian scholars, an action is logical if it is the result of valid instrumental

6 In particular in the Cours, Pareto distinguishes between pure and applied economics (influenced by Walras and most of the theoretical economists of his time), using the methodology of successive approximations. But this distinction did not last long, because few years later with the discovery of sociology, most of the analyses that were supposed to belong to the second approximation of applied economics, fall into the more general sociological synthesis. Nonetheless, in the Manual and in the Treatise (The Mind and Society, 1935 [1916]), the epistemological statute of applied economics was not clear, and surely much less relevant than in the Cours. 
reasoning from objectively true premises. Thus, Pareto begins his exposition of "economic equilibrium" with the declaration that:

We will study the many logical, repeated actions which men perform to procure the things which satisfy their tastes. [...] we are concerned only with certain relations between objective facts and subjective facts, principally the tastes of men. Moreover, we will simplify the problem still more by assuming that the subjective fact conforms perfectly to the objective fact. This can be done because we will consider only repeated actions to be a basis for claiming that there is a logical connection uniting such actions (ibid., ch.3, §I).

Pareto recognises that, as an implication of this definition of "logical" action, his economic theory applies only to a restricted range of human behaviour: "by considering only one part of man's actions and, in addition, by assigning certain characteristics to them, we have simplified the problem enormously. The study of these actions makes up the object of political economy" (ibid., ch.3, §2). So Pareto is proposing a particular definition of the domain of economic theory.

Any such proposal confronts two obvious questions. First, one can ask whether there are operational criteria for determining whether any given class of behaviours falls in the domain of the theory, prior to testing the theory's predictions about that behaviour? Second, one can ask how far the theory's domain, as defined by the proposal, corresponds with existing understandings of the types of problem to which the theory can be applied (if a proposed definition of the domain of economics excludes significant areas of current economic research, one might reasonably expect a convincing justification for that exclusion). I now consider how Pareto responds to these questions.

It should be noticed that Pareto uses two criteria to identify logical actions in economics. The first is that these are actions that are repeated many times. In such situations, he claims, it is reasonable to assume that people's beliefs about the world ("subjective facts") coincide with how the world really is ("objective facts"). In this respect, Pareto anticipates the "discovered preference hypothesis" (Bruni and Sugden, 2007): he restricts the domain of economic theory

7 If the domain of a theory were defined as the class of phenomena about which it makes successful predictions, the theory could never be contradicted. 
to situations in which individuals have had adequate opportunities to learn the consequences of alternative actions. The second criterion is that, for an economic action to be logical, it must be directed towards the satisfaction of tastes through the acquisition of goods. Thus, the rationality of logical actions is instrumental: economic actions (the buying and selling of goods and services) are the means, while the satisfaction of tastes is the end, a methodology that is widespread in contemporary economics. So taken together, Pareto's two criteria are intended to identify a category of actions that are instrumentally rational with respect to what he calls "objective facts". As Pareto puts it in his Trattato (1916, translated into English as: The Mind and Society, 1935), actions are logical to the extent that they "logically conjoin means to ends not only from the standpoint of the subject performing them, but from the standpoint of other persons who have a more extensive knowledge" (ibid., §ı50). Pareto's first criterion, that actions must be repeated many times in order to be identified as logical, imposes a major restriction on the class of phenomena that economics can explain. This criterion may not have excluded much of what nineteenthcentury neoclassical economists sought to explain, but it excludes a huge amount of what later generations of economists have treated as their subject matter-many phenomena that economists study and have studied during the $\mathrm{xx}^{\text {th }}$ century deal with choices that are not necessary repeated and where there can be learning processes: choosing a job, house, wife, children, life insurance, etc. In fact, most of the economic theorists who have seen themselves as Pareto's followers have not applied this criterion. For many commentators, one of the great advantages of grounding economic theory on the logic of rational choice rather than on hedonism is that it widens the domain of the theory.

Probably the first who realised the problems linked to this restriction has been the English economist (and theologian) Philip Wicksteed (1906, p.8I7). In reviewing the Manual of Political Economy in The Economic Journal, he criticises Pareto for having unnecessarily restricted the domain of economics, by not realising how wide a range of human behaviour can be explained in terms of indifference curves. Similarly, Hicks and Allen, in the paper which relaunched Pareto's ideas in the I930s, write: "The methodological implications of [the new] conception 
of utility $[\ldots]$ are far- reaching indeed. By transforming the subjective theory of value into a general logic of choice, they extend its applicability over wide fields of human conduct" (1934, p.45). The restriction operated by Pareto was surely neither popular among later Paretian economists, nor central to Pareto's own economics, that can work also without this methodological constraint.

Pareto's second criterion (that actions must be instrumental in order to be logical) is instead much more essential for his larger conception of social science. Pareto was a sociologist as well as an economist, and most of his methodological efforts were spent in trying to define distinct domains for these two sciences. At least as much as economics, sociology too deals with actions that are constantly repeated (although less than economics: the kind of rationality-non logical actions - in his sociology was different and surely less crucial). Pareto gives as examples a man who removes his hat whenever he enters a drawing room, or a Catholic who regularly attends mass. Notice that these actions satisfy Pareto's first criterion; just as in the case of repeated market transactions, we have reason to expect that the actors' beliefs about the consequences of their actions will converge to the objective facts. However, Pareto claims that these actions fail his second criterion. Rather than being instrumentally rational, they are governed by norms or convention (here one can also find some contact with elements of Weber theory of rationality); people perform them because, on their understanding of the world, "one ought to do so” (197I [1909], ch.2, §2). On Pareto’s account, these actions belong to the domain of sociology, not economics. According to the instrumentality criterion, economic theory applies only to choices that are directed towards the satisfaction of tastes. This immediately raises a question about the empirical bases and "operability" of Pareto's definition of the domain of economics. Considering only the "naked fact of choice", how do we know whether or not a person is motivated by her tastes? We cannot observe motivation itself, and (on Pareto's account) we cannot observe tastes independently of choices. Thus, we cannot identify the situations to which the theory applies, prior to observing the behaviour that it is intended to predict. 
As noted and discussed by Bruni and Sugden (2007), Pareto's instrumentality criterion presupposes some theoretical model of what it is to act to satisfy one's tastes. If the second criterion is to have content, we must be able to define a set of possible end states that can be brought about by economic actions, and over which a person expresses tastes. And if rational choice is to be defined in terms of the satisfaction of tastes, the problem of choosing among actions so as to satisfy tastes must be well defined. That requires that tastes have some formal structure. Exactly what that structure is depends on how rational choice is formalised. For Pareto, who interprets rational choice in terms of constrained maximisation, the requirement is that tastes take the form of an ordering over the relevant set of end states.

\section{THE INTEGRABILITY PROBLEM}

On this requirement rest the roots of Pareto's obsession for the so-called "integrability problem", that occupied most of his theoretical energies between the Italian (1906) and the French (1909) editions of his Manual of Political Economy. The question is: how to derive from the (empirical) indifference curves "rational" utility functions (representations of preferences), and then the supply and demand curves essential for Pareto's equilibrium analysis? To understand his attempts to solve this problem, we must first ask what he means by "tastes". As the passage about "objective facts" and "subjective facts" shows, Pareto assumes that, after sufficient repetition of the relevant choice tasks, tastes "conform perfectly" to relevant objective facts. What kinds of facts are relevant, and what it means for tastes to conform to those facts, are not clear. What is clear is the assumption that, after sufficient repetition, each person has a stable system of tastes, structured in such a way that problems of instrumentally rational choice are well defined. Sometimes Pareto seems to be suggesting that a person can discover his/her true tastes, as if tastes were objective facts in themselves. Thus:

A man who buys a certain food for the first time may buy more of it than is necessary to satisfy his tastes, price taken into account. But in a second purchase he will correct his error, in part at least, and thus, little by little, will end up by procuring exactly what he needs. We will examine this action at the time when he has reached this state. Similarly, if at first he makes a mistake in 
his reasoning about what he desires, he will rectify it in repeating the reasoning and will end up by making it completely logical (197ı [1909], ch.3, §I).

It is tempting to read such passages as relying on an implicit assumption of hedonism: one might think that the "tastes" or "desires" to which behaviour adapts correspond with pleasure, as analysed by other economists of the time. On that interpretation, the transitivity of the taste relation would be implied by the hedonistic assumption that different pleasures for a given individual are commensurable on an ordinal scale. However, although Pareto permits a hedonistic interpretation of tastes, he does not positively endorse it. ${ }^{8}$ On the contrary, he is explicit that he is not assuming hedonism. Drawing a distinction between intrapersonal and interpersonal comparisons of sensations, he says that economics is principally concerned with that class of theories which has as its object:

to compare the sensations of a man in different situations, and to determine which of these he would choose. [...] since it is customary to assume that man will be guided in his choice exclusively by consideration of his own advantage, of his self-interest, we say that this class is made up of theories of egotism. But it could be made up of theories of altruism (if the meaning of that term could be defined rigorously), or, in general, of theories, which rest on any rule, which man follows in comparing his sensations. It is not an essential characteristic of this class of theories that a man choosing between two sensations choose the most agreeable; he could choose a different one, following a rule which could be fixed arbitrarily (ibid., ch.3, §I I) ${ }^{9}$.

8 How far Pareto rejected hedonism is a matter of dispute among historians of thought. Some commentators, such as Stigler (1950), argue that Pareto was inconsistent and failed to follow through the logic of his rejection of "metaphysical" concepts. Bruni and Guala (200I) argue that, from 1900 on, Pareto was consistent in eliminating psychology from the pure theory of economics. Since he did not deny the validity of an introspectively-based analysis of sensations as psychology, his methodological position allowed him to use hedonistic language when interpreting his theory and discussing its practical application.

9 Notice that Pareto is interpreting tastes as subjective comparisons of sensations. So the set of end states over which tastes are defined is the set of possible sensations. However, the ranking of different sensations for a given person need not be in terms of more and less pleasure for that person. The theory assumes only that each person compares sensations according to some fixed rule. 
Given this understanding of tastes, Pareto's problem is to justify the assumption that tastes take the form of an ordering of sensations. What grounds do we have for this assumption? Repetition alone does not provide an adequate explanation. The significance of repetition is that it allows the learning of what Pareto calls objective facts. The relationship between actions and sensations is such an objective fact, and we might expect that with repetition individuals would become able to predict the sensations that would result from alternative actions. But what is at stake here is not individuals' knowledge of the processes that induce their sensations, but the rules they use to compare the sensations themselves. Unless we can assume that people compare sensations as different quantities of some common objective attribute, we seem to have no grounds for assuming that these comparisons are logical (i.e. transitive). Pareto was very conscious of this difficulty for his theory. In mathematical terms, this is the integrability problem. Pareto treats a consumer's marginal rates of substitution at any given point in commodity space as "facts of experience" that in principle can be discovered by observing the consumer's behaviour or relative prices (that are facts of experience).

As it is well known from basic microeconomics, if there are only two goods, this means that one can infer the slope of an indifference curve at each point; by repeated use of this method it is possible to plot a family of indifference curves. But if there are more than two goods, how can we be sure that the marginal rates of substitution we observe at the different points can be integrated into indifference surfaces? In other words: how can we be sure that the consumer's fixed rule - the rule that lies behind the regularities we observe in his behaviour - takes the form of an ordering/rational of end states? Pareto struggled with the integrability problem for many years. He first mentions it in a letter to Pantaleoni in I891, and dedicated a good part of his energies to it in his last works on pure economics (197I [1909], Appendix; 1966 [19I1], p.325, p.342). In a letter to Pantaleoni dated I4 December i89i, Pareto (1984, p.I2I) referred to the mathematician Giovanni Battista Antonelli (1886), who was the first to deal with the integrability problem. Pareto mentioned the integrability problem again in a series of articles on demand theory, in which he specified that "when there are only two goods, the equation [of the indifference curves] 
can always be integrated" (1982 [1892-1893], p.299, footnote). In particular, a paper published by the great mathematician Vito Volterra (I97I [1906]) in Il Giornale degli Economisti, as a comment on Pareto's Manual, criticized Pareto exactly on this issue. Pareto dedicated a long footnote in the 1909 French edition of the Manual, trying to convince (himself first) that there is a solution for such a crucial problem. But the truth is that the problem, as Pareto conceptualised it (by analogy with the problem of "open" and "closed" cycles in thermodynamics), cannot be solved. ${ }^{\circ}$

The significance and centrality of the integrability problem for Pareto's whole "experimental" project seems to have been missed by the theorists who took up his approach in the I930s. Hicks, for instance, criticises Pareto for spending so much energy on the "mysterious problem of open and closed cycles" (1939, p.19). According to Hicks, this problem "fascinates mathematicians, but it does not seem to have any economic importance at all” (ibid.). Of course, the problem is swept under the carpet if one simply assumes that preferences are transitive, as became standard practice in choice theory in the mid-twentieth century. But Pareto's methodological strategy is to create economic theories by deduction from firmly established empirical laws. If economics is to be a separate science, based on laws whose truth is to be treated as axiomatic, we have to be very confident in those laws. Otherwise, we are in danger of creating a complex structure of internally consistent theory, which has no correspondence with reality, and which is not based on the "naked fact of choice". For Pareto, it seems, local indifference-the existence of stable marginal rates of substitution at each given point in commodity space-was a sufficiently solid fact on which to build a theory. But the idea that indifference is transitive right across commodity space was only a speculative hypothesis, for which, at the time he was writing, no solid evidence existed. ${ }^{11}$

10 On the integrability problem and its significance for Pareto, see Chipman et al. (197|), Mirowski (1989) and Bruni (2002).

II The problem of justifying the transitivity assumption does not arise so easily in the hedonistic economics that Pareto challenges. If the sensations resulting from consumption could be measured along a single psychophysical dimension of pleasure, it is immediately obvious that comparisons of sensations must be transitive. But, in the absence of direct evidence of the 
A similar issue arises in relation to the shape of indifference curves. Pareto recognises that, in the overwhelming majority of cases confronted by economists, indifference curves are convex to the origin. However, he also knows that there are occasional anomalous cases in which indifference curves are concave or, in general, not strictly convex (1971 [1909], ch.4, §34, §45). Presumably, and for this reason, he does not feel entitled to treat the convexity of indifference curves as a firmly established empirical law. Thus, for Pareto, the fact that convexity almost always holds can be registered only as a highly reliable but unexplained regularity in tastes. ${ }^{12}$ Notice that Pareto does not challenge the scientific status of psychophysics but only its external validity with respect to economic phenomena. There is an echo here of the scepticism with which many present-day economists view the suggestion that results from experimental psychology might be relevant for economics. Pareto's hedonist opponents took a contrary position. They could reply that, while convexity is not a law of economics, the Fechner-Weber Law is a law of psychophysics, and that that a psychophysical law is useful in explaining the general tendency towards convexity of preferences. The hedonists believed that other reliable generalisations about preferences, beyond transitivity and convexity, could be derived from psychological hypotheses. They no doubt expected that as psychology and economics progressed, still more such generalisations would be found. Pareto's proposal to constitute economics as a separate science seemed to them to be a perverse refusal to use relevant data.

transitivity of indifference, Pareto needs to find a theoretical derivation of transitivity from non-psychological premises.

12 Noting the psychophysical findings of Fechner and Wundt, he explicitly rejects their relevance in explaining convexity of preferences: "in the great variety of economic uses [i.e. cases in which goods are used in some way, but not necessarily consumed], there are many that are too far removed from the phenomena to which Fechner's law applies. It is better to resort directly to experience, and the latter shows us that for a great many uses and consumptions the elementary ophelimity [i.e. marginal utility] does indeed diminish with an increase in the quantities consumed" (197| [1909], ch.4, §33). 
Nevertheless, over the first half of the $\mathrm{xx}^{\text {th }}$ century, Pareto's rationalitybased approach to the theory of choice gradually displaced the psychological approach advocated by Pantaleoni. It seems that Pareto's reservations about the general applicability of the concept of logical action and his concerns about the justification of transitivity were quietly forgotten.

\section{THE NAKED EMPEROR}

Pareto can be seen as the major interpreter of a methodological project that was common in most $\mathrm{xx}^{\text {th }}$ century, very much related to a wider neopositivist and anti-metaphysical philosophy: to show that economics can be a separate science of rational choice, founded on firm empirical bases, and thus independent of any subjective and psychological elements. In trying to achieve this objective and push it ever further, post-Paretian neoclassical economists (Hicks, Allen, Samuelson) faced a common set of methodological problems, two of which are particularly fundamental and particularly difficult to solve. The first problem is to find and to justify a definition of the domain of economics within which rationality-based theories predict successfully: such a definition is not vacuous and is wide enough for economics to have something useful and relevant to say about the real world. The second problem is to find consistency conditions for "rational" or logical preferences, secure enough to serve as the basis for reliable deductive inferences and with enough substance to allow a science of rational choice to have predictive power, without appealing to contestable hypotheses that derive from psychological unstable theory. Pareto and, today, the discovered preference theorists grapple with these problems, but leaving open not only "cycles" of thermodynamics, but many key methodological questions.

For most of the twentieth century, however, without bothering much about these problems, nor taking into consideration Pareto's strict limits assigned to economics, mainstream economics was Paretian and extended economics tools to domains that Pareto should have considered beyond the boundaries of economics (family, religions, politics, altruism, etc.). Limits to the domain of rational choice theory were not discussed by Paretian microeconomics, and 
there was an implicit assumption that the theory was universal in its application. The preferences of economic agents were a priori assumed to satisfy strong axioms of consistency, without any need to test their empirical ground to respond to the many empirical anomalies of the true "naked fact of choice".

But recently behavioural economics remarked that "the emperor was naked". It can no longer be taken for granted that the Paretian turn - the project of separating economics from psychology, of grounding economics on principles of abstract rational choice-was the path of progress in economics.

Maffeo Pantaleoni (I857-I924), probably the only friend Pareto had among leading economists, the one who introduced Vilfredo Pareto to the "new economics" and brought marginalism to Italy, was always convinced that Pareto's turn toward the naked fact of choice was wrong. His Principii di economia pura (1889, translated into English as: Pure Economics, 1898) was considered a real masterpiece of his generation. "We do not know, wrote Irving Fisher reviewing Pure Economics in 1898, where else in English can be found so compact and excellent an epitome of modern economic theory". The Principii di economia pura was Pantaleoni's "gem" (Edgeworth), a book still characterised by the hedonist hypothesis on which economic science is based, and from which every theorem has been derived. In his famous obituary for Pareto, published in the Giornale degli economisti (in 1924), Pantaleoni restated his argument, expressed many times in his work, i.e. that psychological hedonism is more scientific and empirical than other hypotheses upon which choice theory can be based (including Pareto's theory of choice). His reasons were that: a) the past and recent history of economics, from Genovesi to Bentham, from Jevons to Edgeworth has shown the efficiency of hedonistic economics; b) this approach is based on the real observation of concrete reality, i.e. on psychological and biological studies; and c) since people reveal their preferences, economists can know much more about consumer behaviour than natural scientists. 
Pareto's proposal to constitute a new economics (new not only with respect to hedonist first generation neoclassical economics, but also to Walras) as a separate science seemed to them (Pantaleoni, Edgeworth, Jevons, but also for most of the old Italian classics), to be a perverse refusal to use relevant available data. In Pantaleoni's own words:

I claim that we cannot take away from economics the data coming from psychology. I cannot see what, by virtue of this renunciation, we gain, but I see what we lose. [...] I cannot see the convenience of not utilising laws regarding tastes and pains that we know to be true, and that are the reasons of economic actions (1925 [1913], p.8-9).

For a hedonist economist such as Pantaleoni, the domain of economics consists of those situations in which individuals are motivated to seek pleasure, and, even more radically, egoistic pleasure-an economic theory were problems such as "integrability" could never apply. If-as the hedonists assert-introspection is a valid mode of enquiry and if pleasure is measurable, we have an operational criterion for distinguishing economic acts from non-economic ones.

Over the first half of the $\mathrm{xx}^{\text {th }}$ century, Pareto's approach to the theory of choice gradually displaced the psychological approach advocated by Pantaleoni, Jevons and Edgeworth. The end of $\mathrm{XIX}^{\text {th }}$ century was that of Pantaleoni and hedonists; the $\mathrm{xx}^{\text {th }}$ century was dominated by Pareto's economics. The $\mathrm{XxI}^{\text {th }}$ century economics is, up to now, closer to Pantaleoni again. 


\section{BIBLIOGRAPHY}

ANTONELLI G. B., I886, Sulla teoria matematica dell'economia politica, Pisa, Edizioni Fochetto.

BRUNI L., 2002, Vilfredo Pareto and the Birth of Modern Microeconomics, Cheltenham, Elgar.

-, GUALA F., 200I, "Pareto and the Epistemological Foundations of Rational Choice", History of Political Economy, 33, p.21-49.

BRUNI L., SUGDEN R., 2007, "The Road Not Taken: How Psychology Was Removed from Economics, and How It Might Be Brought Back", Economic Journal, II7, p. I46- 173.

BUSINO G., 1964, "Note bibliographique sur le Cours", in Vilfredo Pareto.

Epistolario, p.|l65-1172, Rome, Banca Nazionale del Lavoro.

CHIPMAN J. S., HURWICZ L., RICHTER M. K., SONNENNSCHEIN H.F., I97I, Preferences, Utility, and Demand: A Minnesota Symposium, New York, Harcourt Brace and Co.

EDGEWORTH F., 1967 (I88I), Mathematical Psychics, New York, Kelley.

FECHNER G. T., 1964 (1860), Elemente der Psychophysik, Amsterdam, Bonset.

HICKS J., 1939, Value and Capital, Oxford, Oxford University Press.

-, ALLEN R., 1934, "A Reconsideration of the Theory of Value”, Economica, I-I, Part I, p.52-76; Economica, I-2, Part 2, p.196-219.

JEVONS W.S., 1970 (I87I), The Theory of Political Economy, London, Penguin.

MIROWSKI Ph., 1989, More Heat than Light. Economics as Social Physics, Physics as Nature's Economics, Cambridge, Cambridge University Press.

PANTALEONI M., 1898 (I889), Pure Economics, London, Macmillan.

-, 1924, "In occasione della morte di Vilfredo Pareto-Riflessioni”, Giornale degli economisti, serie quarta, 39-64, p. I-19.

-, 1925 (1913), “Definizione dell'economia. Una prolusione”, Erotemi di economia, I, p.l-66.

PARETO V.,1935 (1916), The Mind and Society, 4 vols, New York, Harcourt, Brace and Co.

-, 1964 (I896-1897), Cours d'Économie politique, Fuvres complètes, t.I-II, Genève, Droz. 
-, 1966 (1894), "Leçon d'ouverture d'économie politique de M. V.P., professeur extraordinaire", in Marxisme et Économie pure, Fuvres complètes, t. IX, Genève, Droz, p.100-101.

-, 1966 (1911), "L'économie mathématique", Statistique et économie mathématique, Fuvres complètes, t.VIII, Genève, Droz, p.319-368.

-, 197I (1909), Manual of Political Economy, New York, Kelley. English translation of the 1909 French edition of the 1906 Italian Manuale d'economia politica con una introduzione alla scienza sociale, Milan, Società Editrice Libraria.

-, 1982 (1892-1893), "Considerazioni sui principi fondamentali dell'economia pura", in Écrits d'économie politique pure, Euvres complètes, t.XXVI, Genève, Droz, p.158-237.

-, 1982 (1900), "Sunto di alcuni capitoli di un nuovo trattato di economia politica del prof. Pareto", Écrits d'économie politique pure, Fuvres complètes, t.XXVI, Genève, Droz, p.365-423.

-, 1984, Lettere a Maffeo Pantaleoni, (1890-1896), Fuvres complètes, t.XXVIII, Genève, Droz.

-, 1989(1899), "Letter to Laurent, 19 January 1899" in Lettres et Correspondances, Fuvres complètes, t. XXX, Genève, Droz.

SAMUELSON P., 1938, "A Note on the Pure Theory of Consumer's Behaviour", Economica, 5, p.61-67.

STIGLER G., 1950, "The Development of Utility Theory: I, II", Journal of Political Economy, 58, p.307-327 and p.373-396.

VOLTERRA V., I97I (1906), "Mathematical Economics and Professor Pareto's New Manual", in Preferences Utility and Demand, edited by J. Chipman, L. Hurwicz, M. Richter and H.H. Sonnenschein, New York, Harcourt Brace and Co., p.365-369.

WICKSTEED Ph., 1906,. "Review of the Manual of Political Economy", The Economic Journal, p.817. 